Medicine (Baltimore). 2012 September ; 91(5): 229-241. doi:10.1097/MD.0b013e31826b145a.

\title{
Cochlear Implantation in Older Adults
}

\author{
Frank R. Lin, MD, PhD ${ }^{1,2,3}$, Wade W. Chien, MD $^{1}$, Lingsheng Li, M. H. S. ${ }^{3}$, John K. Niparko, \\ MD ${ }^{1}$, and Howard W. Francis, MD ${ }^{1}$
}

${ }^{1}$ Department of Otolaryngology-Head \& Neck Surgery, Johns Hopkins School of Medicine, Baltimore, Maryland ${ }^{2}$ Department of Epidemiology, Johns Hopkins Bloomberg School of Public Health, Baltimore, Maryland ${ }^{3}$ Center on Aging and Health, Johns Hopkins Medical Institutions, Baltimore, Maryland

\begin{abstract}
Cochlear implants allow individuals with severe-to-profound hearing loss access to sound and spoken language. The number of older adults in the United States who are potential candidates for cochlear implantation is approximately 150,000 and will continue to increase with the aging of the population. Should cochlear implantation (CI) be routinely recommended for these older adults, and do these individuals benefit from CI? We reviewed our 12 year experience with cochlear implantation in adults $\geq 60$ years $(n=445)$ at Johns Hopkins to investigate the impact of CI on speech understanding and to identify factors associated with speech performance. Complete data on speech outcomes at baseline and 1 year post-CI were available for 83 individuals. Our results demonstrate that cochlear implantation in adults $\$ 60$ years consistently improved speech understanding scores with a mean increase of $60.0 \%$ (S. D. 24. 1) on HINT sentences in quiet . The magnitude of the gain in speech scores was negatively associated with age at implantation such that for every increasing year of age at $\mathrm{CI}$ the gain in speech scores was 1.3 percentage points less (95\% CI: $0.6-1.9$ ) after adjusting for age at hearing loss onset. Conversely, individuals with higher pre-CI speech scores (HINT scores between 40-60\%) had significantly greater post-CI speech scores by a mean of 10.0 percentage points $(95 \%$ CI: $0.4-19.6)$ than those with lower pre-CI speech scores (HINT <40\%) after adjusting for age at CI and age at hearing loss onset. These results suggest that older adult CI candidates who are younger at implantation and with higher preoperative speech scores obtain the highest speech understanding scores after cochlear implantation with possible implications for current Medicare policy. Finally, we provide an extended discussion of the epidemiology and impact of hearing loss in older adults. Future research of $\mathrm{CI}$ in older adults should expand beyond simple speech outcomes to take into account the broad cognitive, social, and physical functioning outcomes that are likely detrimentally impacted by hearing loss and may be mitigated by cochlear implantation.
\end{abstract}

\section{Introduction}

Hearing aids can improve the communicative abilities of most individuals with hearing loss, but amplification in individuals with more severe hearing loss may not sufficiently improve the individual's word discrimination and speech understanding abilities. When hearing deficits progress beyond the ability of hearing aids to produce meaningful benefit, a cochlear implant $(\mathrm{CI})$ provides an alternative hearing rehabilitative modality by stimulating the auditory nerve and nervous system directly. A cochlear implantation typically entails a two

Address correspondence, reprint requests, and proofs to: Frank R. Lin, Johns Hopkins Center on Aging \& Health, 2024 E. Monument St, Suite 2-700, Baltimore, MD 21287, Telephone: (443) 287-6509, Fax: (410) 614-9444 flin1@jhmi.edu.

Potential conflict of interest: None reported 
hour outpatient surgery, and activation of the cochlear implant occurs four weeks after surgery. During surgery, the receiver-stimulator device and electrode array is inserted into the basal turn of the cochlea (Figure 1). After implant activation, sound is detected by the external processor, transmitted wirelessly to the implanted receiver-stimulator device, and then converted to synchronized electrical impulses which are delivered through the electrode array to the spiral ganglion (hearing) nerve. Sound is therefore transmitted to the hearing nerve bypassing the impaired cochlea. Patients receiving cochlear implants typically require 6-12 months of experience and practice with the cochlear implant before optimal hearing and speech understanding results are achieved.

Currently, over 16 million adults in the United States over 70 years have hearing loss (79) and greater than 150,000 of these adults likely have hearing loss of a severity that would meet cochlear implantation candidacy criteria (80). With the aging of the U. S population, the number of individuals with hearing loss and meeting auditory criteria for CI will continue to increase. Should cochlear implantation be routinely recommended for these individuals and will they benefit from the device? What impact does hearing rehabilitation with a cochlear implant have on an older adult? These questions lie at the heart of understanding the role of cochlear implantation in older adults and are of paramount importance given increasingly scarce healthcare resources. We review our experience with cochlear implantation in older adults at Johns Hopkins over the last 12 years focusing on the impact of the cochlear implant on speech understanding and identifying factors that are associated with speech outcomes. We conclude with an extended discussion of the potential impact of hearing loss and hearing loss treatment on human health and functioning.

\section{Methods}

\section{Study Cohort}

Study participants are individuals $\geq 60$ years receiving a first cochlear implant at the Johns Hopkins Listening Center from 1999 to June 2011. The Johns Hopkins Listening Center maintains a clinical database of all cochlear implant recipients in which data on speech testing scores and clinical variables related to cochlear implant programming visits are stored. Data on hearing loss onset ( $<18$ years vs. $\geq 18$ years) were based on clinician interview and patient self-report. We queried this database to retrieve all patients $\geq 60$ years who received a first cochlear implant since 1999. This study was approved by the Johns Hopkins Institutional Review Board.

\section{Speech testing}

Individuals undergoing CI routinely receive a battery of speech and audiometric tests both pre and post-operatively. Pre-operative speech testing is generally performed in the 6 months prior to surgery except in cases where surgery is scheduled greater than 6 months after testing because of surgical scheduling issues. Various different speech tests are used depending on audiologist preference and patient ability, and these tests include HINT (Hearing in Noise Test) sentences, CNC (Consonant-Nucleus-Consonant) word lists, and AZBio sentences. Individuals undergoing CI may receive any one or a combination of these tests, and these tests can also be performed under different conditions (e. g binaural aided conditions, monoaural aided conditions, different speech presentation levels). HINT sentence testing in soundfield was the most commonly administered speech test from 19992011, and this test is comprised of a list of 20 recorded sentences that are presented to the patient in quiet in a sound booth. The patient's speech score is calculated as the percent of words repeated back correctly. We analyzed a subset of patients who had HINT speech tests available both pre-operatively and approximately 1 year post-CI activation (range 9-14 months). One subject had post-CI speech data assessed at 21 months after CI activation 
because of a delay in CI programming related to vestibular schwannoma surgery 9 months after her CI activation. Data were manually filtered to select patients in whom HINT testing scores were performed under as similar conditions as possible. In this analytic subset of 83 patients, HINT testing scores that were retained were always presented at identical presentation levels (e. g. 60dB) both pre and post-operatively. Patients were always tested under binaural best-aided conditions pre-operatively, and post-CI HINT speech scores were generally done under CI-only conditions with the exception of 9 individuals who were tested at 1 year under binaural best aided conditions.

\section{Statistical Analysis}

Data were queried from the Listening Center database and manually cleaned to ensure data integrity. Exploratory data analyses consisted of graphical displays and using nonparametric, lowess smoothers to model data and observe for data trends. Chi-square or Fisher exact tests (for categorical data) and paired or 2-sample t-tests (for continuous data) were used as appropriate to compare values between groups. Linear regression was used to model the association of independent variables (age, pre-operative speech scores) with dependent variables (change in HINT speech score, Year 1 HINT score) after adjusting for potential confounders (i. e. age at CI, age at hearing loss onset [ $<18$ years vs $\geq 18$ years]). All data analyses were performed in Stata 11. 2 (Stata Corp., College Station, TX). A twosided $a$ of 0.05 was considered to be statistically-significant.

\section{Results}

Over the past decade, the number of cochlear implants performed in adults 60 years or older at Johns Hopkins has continued to increase annually (Figure 2). From 1999 to 2011, a total of 445 older adults received a first cochlear implant at Johns Hopkins. Nearly $60 \%$ of these implantations were performed in adults over 70 years with the oldest recipient being almost 95 years at implantation. Over three-quarters of these older adult CI recipients had hearing loss that developed in later life rather than being of congenital or early onset (Table 1).

We examined the impact of cochlear implantation on a CI recipient's ability to understand speech by analyzing performance on HINT speech testing performed in quiet before and after cochlear implantation. Of the 445 older adults receiving cochlear implants over the last 12 years, 83 patients had speech assessments with HINT sentences performed both preoperatively and 1 year post-CI activation under similar conditions (Table 1). The baseline characteristics of these 83 patients did not differ appreciably across baseline characteristics than the 362 patients with incomplete data. The $362 \mathrm{CI}$ recipients with incomplete HINT speech scores had speech data that did not allow for pre to post-CI analysis. These patients underwent speech testing in which different tests were used pre and post-operatively and/or testing was performed under different testing conditions (e. $\mathrm{g}$ speech tests were performed at $70 \mathrm{~dB}$ pre-operatively but $60 \mathrm{~dB}$ post-operatively). In Figure 3, we examine HINT speech scores from pre to 1-year post-CI in these 83 individuals. All patients had improved speech scores after CI with mean pre-CI HINT speech scores of $19.8 \%$ (S. D. 2. 0) improving to 79. $8 \%$ (S. D. 2. 1) after implantation (p < .001).

We further explored whether age at implantation was associated with the magnitude of the change in HINT speech scores. Figure 4 demonstrates a linear association of age at implantation with change in HINT speech scores using a non-parametric smoother. Linear regression was used to model this association and to adjust for age of hearing loss onset given the known association between duration of hearing loss and CI outcomes. In this model, $17 \%$ of the variance in the speech data could be explained by age at implantation. For every increasing year of age at time of CI, the magnitude of the change in HINT speech scores from pre to post-CI declined by $1.3 \%$ (95\% CI: $0.6-1.9)$. On average, a 60 year- 
old adult undergoing CI would expect a 75 percentage point improvement in HINT speech scores whereas an 80 year-old adult would experience a 50 point improvement.

We also investigated the association of pre-CI speech scores with post-operative outcomes. Federal Food and Drug Administration (FDA) regulations permit cochlear implantation in individuals with pre-operative speech scores up to 60\%. However, current Center for Medicare Services (CMS) stipulations limit coverage for CI to individuals scoring less than $40 \%$ on preoperative testing due to possible concerns of whether patients with better baseline speech ability (i. e. preoperative speech scores between 40-60\%) benefit from a CI. Figure 5 demonstrates the change in HINT speech scores from pre to post-CI in individuals with pre-CI HINT speech scores of $<40 \%$ (mean 12. 8 [S. D. 12. 9]) versus 40-60\% (mean 47. 5 [S. D. 6. 5]). While the magnitude of the change in HINT speech scores was greater in individuals with pre-CI scores of $<40 \%$ owing to their lower pre-CI values(mean change 64 . 6 [S. D. 24. 5] vs. 42.2 [S. D. 10.6]), speech scores at 1 year post-CI were on average higher in those individuals with greater pre-CI speech scores (Post-CI speech score of 89. $7 \%$ [S. D. 2. 2] vs. 77. 3\% [S. D. 2. 5] in individuals with pre-CI speech of $40-60 \%$ vs. $<40 \%$, respectively [p<. 001]). The observation of pre-CI speech scores between $40-60 \%$ being associated with higher post-CI speech scores persisted after adjustment for age at CI and age of hearing loss onset in regression models. On average, individuals with pre-CI speech scores of 40-60\% had post-CI HINT speech scores 10.0 percentage points (95\% CI: $0.4-19.6, \mathrm{p}=.04$ ) higher than individuals with pre-CI speech scores $<40 \%$ after adjusting for age at implantation and age at hearing loss onset.

\section{Discussion}

\section{Findings from the current study}

In this study of our 12 year experience with older adult CI at Johns Hopkins, cochlear implantation in adults $\geq 60$ years consistently led to improved speech understanding among all adults with a mean gain of 60 percentage points on HINT sentences in quiet. The magnitude of the gain in speech scores was negatively associated with age at implantation such that for every increasing year of age at CI, the magnitude of the expected gain in speech scores was 1.3 percentage points less. Conversely, individuals with higher pre-CI speech scores (HINT scores between 40-60\%) had significantly greater speech scores one year after implantation than those with lower pre-CI speech scores (HINT <40\%). Taken together these findings suggest that older adult CI candidates who are younger at implantation and with higher preoperative speech scores may derive the greatest benefit (i. e. highest speech understanding scores) after cochlear implantation.

Our results contribute to the literature examining the impact of cochlear implantation on speech understanding in older adults. The effect of age at implantation versus duration of hearing loss on speech perception scores after CI has been the subject of much debate in the literature $(24,26,75,84,134)$. Distinguishing between the effects of these factors is difficult to establish given that duration of hearing loss and age at CI are highly co-linear and the exact onset of hearing loss for most adults with age-related hearing loss is generally impossible to determine. From a more pragmatic standpoint, the association of these factors with speech outcomes are not mutually exclusive, and both are likely to exert an effect on speech perception outcomes. Our current results suggest that after accounting for hearing loss onset as a binary covariate (onset at $<18$ years vs. $\geq 18$ years), age at implantation remained significantly associated with CI outcomes. A likely mechanistic explanation for this association is that top-down cognitive processing is required for auditory processing and decoding of the input provided by the $\mathrm{CI}(127)$, and these cognitive resources are known to decline with age $(106,107)$. 
Our results also demonstrate that pre-operative sentence scores were significantly associated with speech perception gains after CI, and these findings are consistent with previous research $(44,104)$. Conceptually, this association suggests that a greater foundation of peripheral auditory processing capacity as indicated by pre-operative speech scores may be critical to speech recognition after cochlear implantation. When considered in combination with a strong association between speech perception gains and health related quality of life outcome (41), the importance of early intervention comes into sharper focus. The delay of $\mathrm{CI}$ candidacy in older adults under current CMS criteria (restricting cochlear implantation to only individuals with pre-operative speech scores $<40 \%$ ) may prevent some patients from using the $\mathrm{CI}$ to its fullest potential. Expanding current CMS criteria to mirror current FDA guidelines allowing for $\mathrm{CI}$ in adults with preoperative speech scores $<60 \%$ would allow for $\mathrm{CI}$ candidates who are younger at implantation and with better preoperative speech scores. These factors may allow patients to derive the greatest benefit from cochlear implantation, thereby leading to greater quality of life gains and cost-effectiveness when considered over the patient's lifetime.

Our study has limitations. Data were queried from a clinical database rather than a database designed specifically for prospective research. As such, the availability of speech testing data was dependent on clinical variables such as patient availability and audiologist preference regarding test choice and administration. In analyzing only the subset of patients in our database with speech tests consistent in pre and post-CI administration, there is the possibility of selection bias in the studied subset. In particular, there is the concern that our dataset only includes those patients who are higher functioning and with better outcomes leading to bias in our reported results. While we acknowledge this possibility and note that this limitation is common to analyses based on clinical databases, we believe that our results in fact may be overly conservative. Testing is often inconsistent from pre to post-CI for many subjects because HINT testing in quiet often reaches ceiling effects for CI patients at 1 year (48). As such, more difficult tests such as CNC single word lists that eliminate contextual clues or AZBio sentences are often used instead. These higher-functioning patients may not have had HINT testing completed at 1 year and are therefore not included in our analyses. Efforts to standardize speech testing within and across cochlear implants centers have resulted in the recent industry adoption of a revised Minimum Speech Test Battery that will likely improve analyses of CI speech results going forward.

Caution must also be applied when interpreting our findings in clinical situations. For example, the association of HINT scores with age at implantation demonstrated substantial variance. Thus, while a 1.3\% decline in HINT score change was observed for every increasing year of age at implantation, this value represents a mean estimate important from a policy perspective but perhaps less so for individual patient counseling. Our results are also limited by only providing insight into the impact of $\mathrm{CI}$ in the 1 year period after CI. There is currently little published literature on the long-term outcomes of $\mathrm{CI}$ in older adults, and further studies will be needed to understand the long-term (>1 year) effects of CI on speech understanding and other functional domains.

\section{Epidemiology and impact of hearing loss in older adults}

In order to understand the role of cochlear implantation in older adults, it is important to examine the broader context of how hearing loss impacts older adults. However, nearly all current literature on cochlear implantation in older adults focuses on only studying the effects of cochlear implantation on speech understanding rather than investigating the effects of CI on broader, more important downstream health and functional outcomes. Herein, we review the pathophysiology and epidemiology of age-related hearing loss and propose a conceptual model for better understanding the impact of hearing loss on older adults and the effects of rehabilitative therapies such as cochlear implantation. 


\section{A. Overview of presbycusis pathophysiology}

A. 1. Introduction-Hearing depends on a series of physiologic events that occur in a pathway from the external ear canal to the temporal lobe. The pinna, ear canal, and tympanic membrane passively gather acoustic vibrations that are transmitted to the ossicular chain. Mechanical energy is then transmitted to the fluid-filled cochlea. Here, a complex of sensory epithelium - the hair cells of the Organ of Corti-transduce vibromechanical energy into a neural signal, which is transmitted by the auditory nerve fibers into the brain. Presbycusis reflects progressive injury and dysfunction of the hair cell/auditory nerve system that is responsible for auditory signal transduction within the cochlea $(95,113)$.

\section{A. 2. Cochlear structure and function}

Mechanisms of presbycusis reflect the sensitivity of cochlear mechanics. The cochlea is a snail-shaped organ comprised of two and a half turns. It measures approximately one inch in linear length and consists of three compartments: scala vestibuli, scala tympani, and scala media (Figure 6). While the scala vestibuli and scala tympani contain perilymph with an ionic concentration similar to that of extracellular fluid (high in sodium and low in potassium), the scala media contains endolymph with an ionic concentration similar to intracellular fluid (high in potassium and low in sodium), resulting in an endolymphatic potential of approximately $80 \mathrm{mV}$. This resting potential is maintained through metabolically-demanding $\mathrm{Na}+\mathrm{K}+\mathrm{ATPase}$ pumps concentrated in the stria vascularis along the lateral cochlear wall.

Vibromechanical energy transmitted by the ossicular chain enters the scala vestibuli through the oval window at the base of the cochlea. Vibratory energy progresses as a travelling wave within the cochlea. This travelling wave results in displacement of the basilar membrane and Organ of Corti where neural transduction of the auditory signal occurs. Deflection of the inner hair cell stereocilia in the Organ of Corti by the traveling wave opens mechanotransducer ion channels, leading to $\mathrm{K}+$ influx and depolarization of the inner hair cell. Inner hair cell depolarization trans-synaptically generates compound action potentials within auditory nerve fibers, and neural traffic to the brain. The inner hair cells and the auditory nerve fibers are tonotopically organized, i. e. hair cells within each region of the cochlea, along with the auditory nerve fibers they innervate, are most sensitive to specific frequency ranges. The precise frequency selectivity and sensitivity of inner hair cells to specific sound frequencies are maintained by an active process termed the cochlear amplifier whereby the outer hair cells help to selectively sharpen the tuning of the inner hair cells, and this process is dependent on the endocochlear resting potential generated by the stria vascularis (95). Consequently, complex sound signals comprised of multiple different frequencies, harmonics, and intensities can be faithfully transduced into neural signals (Figure 7).

\section{A. 3. Mechanisms of presbycusis}

Presbycusis results from impairment of cochlear transduction. Potential sites of lesion include the inner and outer hair cells, the stria vascularis, and afferent neurons. Presbycusis reflects cochlear aging, environmental factors, genetic predisposition, and is associated with other health comorbidities $(91,113,114,131)$. The stria vascularis and hair cells are particularly susceptible to injury. The stria vascularis carries blood supply to the organ of Corti and is highly metabolically active. The stria depends on an elaborate cellular machinery to maintain the steady-state endocochlear resting potential. Consequently, injury from multiple different pathways (e. g. age-related cell losses within the stria, oxidative stress from noise exposure, genetic polymorphisms leading to inefficient oxidative pathways or dysfunctional supporting cells, or hypertensive microvascular disease in the strial vessels) could all affect strial function $(90,91)$. The resulting loss of the endocochlear potential 
would impair the function of the cochlear amplifier and lead to an increase in hearing thresholds $(109,115)$.

A similar multimodal pathway of injury and dysfunction can also be seen in the hair cells. These cells are post-mitotic and cannot be replaced, and are therefore susceptible to accumulated injury over time from a combination of poor cellular repair mechanisms associated with aging, direct mechanical or mitochondrial oxidative injury from noise, and toxicity from aminoglycosides or other ototoxic medications $(81,90,95)$.

The complexity and the interactions of the different mechanistic pathways and the number of factors (aging, genetic, environmental, health comorbidities) that can cause presbycusis have greatly complicated prior basic and clinical research into presbycusis (131) and have led to some latent cynicism about the value of precisely determining all the various causes and forms of presbycusis (91). In particular, the same functional consequences of increased hearing thresholds and poor frequency resolution generally occur regardless of presbycusis etiology or the cochlear mechanistic pathway (95).

To illustrate, if the neural output produced by a normal cochlea can be imagined as the complex spectrogram in Figure 7 containing sharp peaks (good frequency resolution) for both low and high amplitude auditory signals (normal hearing thresholds), the neural output from a presbycusic cochlea would be represented by a spectrogram with dull, flat curves (poor frequency resolution) and many missing low intensity (amplitude) auditory signals. Even in individuals with early hearing loss, where auditory thresholds may not be substantially elevated, the poor frequency resolution is still noticeable. Consequently, adults with early presbycusis will report that they can hear but that they cannot understand, and they will confuse words such as shop/shot/shock or fine/shine/sign in which the fine auditory cues encoding semantic meaning are not faithfully transduced by the impaired cochlea.

\section{B. Hearing Loss Epidemiology}

B. 1. Prevalence-Estimating hearing loss prevalence and identifying epidemiologic risk factors can be best ascertained from large cohorts where formal audiometric testing was performed. Such studies include Beaver Dam (34, 35), Framingham (46), Blue Mountains (50), Baltimore Longitudinal Study of Aging (BLSA) $(15,16)$, and National Health and Nutrition Examination Survey (NHANES) (1). Reports of hearing loss prevalence across these studies vary because of different tonal frequencies utilized to obtain a pure tone average (PTA), monaural or binaural definition of hearing loss, and audiometric cutoffs used to define hearing loss. Differences in cohort characteristics (volunteer cohort or recruitment of population sample) and the age of the cohort also limits comparisons across studies.

A useful audiometric definition of hearing loss has been adopted by the World Health Organization as a PTA of $0.5-4 \mathrm{kHz}$ tone thresholds in the better-hearing ear $>25 \mathrm{~dB}(140)$. The selected tonal frequency range and the use of the better-hearing ear are useful from a pragmatic perspective that emphasizes communication since $0.5-4 \mathrm{kHz}$ represents the critical frequency range of speech and the better-hearing ear would be the principal determinant of a person's communicative abilities. Using this WHO-adjudicated definition of hearing loss and NHANES data (representing a cross-section of the non-institutionalized U. S. population), hearing loss prevalence approximately doubles every decade of life from the second through seventh decades (Figure 8) (80).

Other reports of hearing loss prevalence have generally focused on older adults using differing definitions of hearing loss. Prevalence rates have been $29 \%$ ( $>26 \mathrm{~dB}$ in the standard PTA $[0.5-2 \mathrm{kHz}]$ in the better ear, subjects $>60$ years), $73 \%$ ( $>25 \mathrm{~dB}$ in the 
speech frequency [0.5 - $4 \mathrm{kHz}]$ PTA in the worse ear, subjects $>70$ years), and $60 \%$ (>25 $\mathrm{dB}$ in the standard PTA in the worse ear, subjects 73-84 years) in the Framingham (46), Beaver Dam (35), and HealthABC (57) studies, respectively. Using identical definitions of hearing loss and age ranges from the latter two studies, prevalence figures calculated using the 2005-2006 NHANES dataset would be $76 \%$ and 64\%, respectively (80). However, comparing results across different studies is difficult even when applying the same definition of hearing loss given the different demographic characteristics across cohorts particularly with regard to age and race. For example, both the Framingham cohort and Beaver Dam cohorts included few black individuals, but the HealthABC cohort was 36. 3\% black. Age distributions and ranges also varied across these study cohorts. A strength of using NHANES estimates of hearing loss prevalence are that these results are generalizable to the entire civilian, non-institutionalized U. S. population (Figure 8).

B. 2. Risk factors for hearing loss-Epidemiologic studies also provide insight into the modifiable and non-modifiable risk factors associated with hearing loss and provide further insight into the mechanistic pathways underlying presbycusis. Studied risk factors can generally be (32-34) divided into four categories as discussed previously: cochlear aging (individual age), environment (occupational and leisure noise exposure, ototoxic medications, socioeconomic status), genetic predisposition (sex, race, specific genetic loci/ genes), and health co-morbidities (hypertension, diabetes, stroke, cigarette smoking). Strong and consistent associations of hearing loss have generally been found with the nonmodifiable risk factors of increasing age (increased risk), male sex (increased risk), and black race (decreased risk) $(1,15,16,46,57,63,65)$. Genetic predisposition as shown by heritability studies among twins and longitudinal studies of family cohorts have also shown heritability indices of $0.35-0.55(28,47,70)$, indicating that genetic phenotype accounts for a substantial portion of hearing loss risk. Other factors have shown slightly less consistent associations with hearing loss risk: hypertension and cardiovascular disease, cerebrovascular disease, smoking, diabetes, noise exposure, and alcohol consumption (all factors associated with increased risk of hearing loss except for alcohol consumption) (35, $37,45,57,131)$.

The inconsistent findings with the latter group of risk factors may be a consequence of how hearing loss was defined and the characteristics of the study cohort. For example, noise exposure may primarily lead to high-frequency hearing loss whereas cardiovascular riskfactors affect both low and high-frequencies. Averaging across frequencies when defining a pure tone average could, therefore, obscure certain associations depending on which tonal frequencies are selected for the PTA. Characteristics of the study cohort may also obscure potential associations depending on the risk factors present in the risk group. For example, in a study focused on only older adults, the factors associated with older age and cochlear aging may overshadow associations with these weaker risk factors. Genetic heterogeneity within cohorts with consequent variability in gene-risk factor interactions $(81,131)$ would also likely bias any possible association toward the null hypothesis.

\section{B. 3. Further research into hearing loss risk factors and prevention-Previous} research into hearing loss epidemiology has emphasized the study of modifiable risk factors in order to form the basis for possible hearing loss prevention strategies. However, the contribution of these modifiable risk factors (e. g. hypertension, smoking, etc. ) is relatively weak in comparison to the non-modifiable risk factors of genetic predisposition and race as demonstrated by the consistency and strength of associations seen in epidemiologic studies. Further study of these non-modifiable risk factors, particularly the physiologic basis of black race being a protective factor for hearing loss and the identification of the genetic loci and genes contributing to presbycusis, could possibly offer the most substantial and profound insights into actual hearing loss prevention. 
Previous observational studies investigating the role of race and hearing loss have consistently demonstrated that black race is associated with a 60-70\% lower odds of noiseinduced hearing loss and presbycusis compared to white subjects $(1,32,57)$. Other epidemiologic studies using a case-control approach recruiting individuals with similar occupational exposures have also demonstrated a reduced risk of hearing loss in black subjects $(63,65)$. Current hypotheses focus on the possible protective role of melanocytes in the stria vascularis (7), but experimental animal studies studying skin pigmentation and hearing loss have been inconclusive and have not resulted in further research (8). There have not been any further epidemiologic studies exploring the issue of race and hearing loss, basic science research into the development of other potential animal models, or genetic epidemiologic approaches toward investigating whether a genetic etiology could explain the protective association of black race with hearing loss. The lack of research exploring these topics is surprising given the strength of the epidemiologic association between race and hearing loss relative to other factors that have received more concerted attention.

Given the strong genetic basis underlying presbycusis, there has also been little research using powerful and state-of-the-art genome wide association studies (GWAS) to understand the multigenic basis for presbycusis and gene-environment interactions. Genetic studies of hearing loss have focused almost exclusively on linkage analysis (131) to identify monogenic forms of deafness and hearing loss in which there is a strong genotypephenotype correlation $(38,73,81)$. Genetic polymorphisms associated with presbycucis, however, are likely susceptibility alleles with a weak genotype-phenotype correlation and are poorly suited to linkage analyses even when these analyses are nested within large families offering more statistical power. To date, only a few GWAS studies have been performed $(3,62,73,130-133)$, and these studies have been limited in only studying a certain subset of potential genes or markers (i. e. those associated with monogenic forms of deafness) rather than examining a broad array $\left(>10^{6}\right)$ of various polymorphisms. Ultimately, comprehensive GWAS studies of presbycusis offer the potential to identify those genetic loci and genes heretofore unknown with respect to hearing loss that may be associated with hearing loss and possibly other aspects of neuronal or cognitive aging (e. g. candidate genes could be those that underlie mitochondrial function and survival).

\section{Impact of Hearing Loss in Adults}

C. 1. Conceptual Model-A conceptual model of hypothesized and established associations between hearing loss and domains of health and functioning allows for an understanding of the potential impact of hearing loss in adults (Figure 9). Prior research investigating the effects of hearing loss has focused on relatively more proximal outcomes such as communication impairments, health-related quality of life (HRQoL), and depression. These studies have demonstrated a consistently negative impact of hearing loss on communication $(39,51,54,61,139)$ and $\operatorname{HRQoL}(22,27,37,86,126)$, and mixed effects on depressive symptoms $(20,50,58,67,69,124)$. Past research into hearing loss and more critical downstream domains have demonstrated possible associations with dementia (64, $129)$, functional activities $(12,20,36,122,136)$, and mortality $(2,6)$. These studies, however, have been limited by cross-sectional or retrospective design, limited study cohorts, or use of only subjective assessments of hearing loss status. Most recently, however, using the prospective cohort of the Baltimore Longitudinal Study of Aging, researchers have demonstrated that audiometric hearing loss is an independent risk factor for incident dementia (78), and these results may serve as a much needed impetus for further highquality prospective research into the functional consequences of hearing loss hypothesized by this conceptual model. C. 2. Causal pathway of communication impairments and social isolation Verbal communication is particularly susceptible to the effects of hearing loss given the inherent properties of spoken language. The components of spoken language 
consisting of the linguistic subsystems of phonology, semantics, and syntax are often encoded subtly in the auditory stream (e. g. "Sunday" and "someday" while phonetically similar have markedly different meanings in conversation). Presbycusis leads to decrements in auditory sensitivity and loss of frequency resolution which compromises an individual's access to these fine auditory cues (95). These effects result in degraded verbal comprehension and impaired communication, particularly in situations with poor signal-tonoise ratio where effective communication is most critical (e. g. conversing with friends/ family at dinner, participating in a meeting) $(39,51,54,61,139)$. Degraded communication can subsequently lead to impaired social functioning as demonstrated in several studies of older adults $(17,74,99,122,125,138)$.

\section{3. Causal pathway of cognition and cognitive load}

Operational definition: Cognition can be understood to represent mental processes that allow for information processing, access, and storage and includes domains such as verbal and nonverbal memory, visuospatial ability, and executive function. While some domains (e. g. executive function) are functionally and neuroanatomically well-delineated, other cognitive domains such as working memory and processing speed are required for multiple cognitive abilities and subserved by a widely distributed neural network $(19,106)$. Cognitive load refers to the cognitive effort required for a set of cognitive tasks. Using the model of resource capacity developed by Kahneman (68), difficulty in doing multiple tasks is related to the limited pool of available cognitive resources, and simultaneous performance of tasks is feasible only when resource capacity limits are not exceeded.

Cognitive psychology studies over the past 40 years have consistently demonstrated that hearing loss is associated with poorer performance on auditory and non-auditory cognitive measures of working memory as first described by Rabbitt (97). These studies have generally tested the working memory of adults who are tested under conditions of normal versus artificially-degraded hearing or in matched pairs of adults with and without hearing loss $(25,52,55,82,83,87,88,94,96,97,110-112,127)$. Under degraded auditory conditions and/or hearing loss, adults do poorer on tests of working memory where the confounding effect of participants' simply not being able to understand the verballypresented tasks is eliminated by "shadowing" (i. e. participants are able to repeat back what is said to them indicating reception of the spoken message). These results suggest that hearing loss imposes top-down, auditory perceptual processing requirements that result in a smaller pool of resources being available for other cognitive tasks as consistent with Kahneman's resource capacity model (127). Based on this model, the load on cognitive resources induced by hearing loss would lead to decrements in overall resource capacity, and these effects would be most pronounced under cognitive loads that overwhelm available cognitive resources (Figure 10). Of note, the effects of hearing loss on resource capacity in this model are independent of the progressive decrements in processing resources associated with aging $(106,107)$. Consistent with this hypothesis, recent population-based crosssectional studies have demonstrated that hearing loss is independently associated with both verbal and non-verbal measures of cognitive ability $(76,77)$.

C. 4. Potential effects mediated through social isolation-Social relationships have powerful effects on physical and mental health that have been recognized since Durkheim first described the relationship between social integration and suicide in 1897 (40). Subsequent prospective studies have consistently implicated a causal effect of poor social relationships on all-cause mortality $(18,60,117)$, cognitive decline $(4,5,9,10,59$, 141), dementia $(13,42,56,71,105,108,137)$, heart disease $(98,103,135)$, physical functioning $(85,93,100,121)$, institutionalization $(43,119)$, gene expression profiles $(29$, $30)$, and depression $(49,72,92)$. 
A conceptual framework developed by Berkman (11) to explain these effects hypothesizes that an individual's social network provides opportunities for social support, social influence, social engagement, person-to-person contact, and access to resources. These mechanisms in turn influence health though behavioral, psychologic, and physiologic (e. g poorer immune, neuroendocrine, and cardiovascular function $(116,118,128)$ ) pathways. Interestingly, while the downstream effects of social isolation have been extensively studied, little research has been done on upstream factors that lead to social isolation (60) with most of the current research in this field focused on macroscopic factors such as cultural and political forces that shape social networks (11). Hearing loss has been shown to be associated with social functioning $(17,74,99,122,125,138)$, but there has been little research investigating the mechanism through which this occurs. For example, perceived social isolation or "loneliness" (21) rather than objective network size (i. e. quality over quantity) may be the critical determinant that characterizes social isolation in individuals with hearing loss, but this distinction has not been made in prior studies.

\section{5. Potential effects mediated through cognitive load}

Operational definition: Cognitive reserve reflects inter-individual differences in task processing that allow some individuals to cope better with neuropathology than others (120) and has been used to account for the poor correlation observed between clinical symptoms of dementia and the degree of neuropathology seen on post-mortem exam (89). As a theoretical construct, cognitive reserve cannot be measured directly but is conceptualized as being related to lifetime experiences, and proxies for cognitive reserve are socioeconomic status, education, and occupational attainment $(31,42)$.

The downstream implications of reduced cognitive resources caused by hearing loss observed in clinical psychological studies remain unexplored. Two potential pathways are through effects on cognitive reserve and/or executive function. The role of cognitive reserve in buffering neuropathology could be impaired under conditions where processing resources such as working memory are limited (14). In such a model, reduced cognitive resource capacity associated with hearing loss would impair cognitive reserve and lead to earlier expression of dementia pathology. Indeed, a recent prospective study (78), has demonstrated that hearing loss is an independent risk factor for incident dementia and that this association could be mediated through effects on cognitive reserve, social isolation, and or more speculatively, through a shared neuropathological or genetic etiology (e. g. mitochondria dysfunction). Another pathway through which reduced cognitive resources could manifest is through impairment of executive function. Executive functions encompass processes that require the goal-oriented organization of information in working memory for the execution of complex tasks (123), and measures of executive function have been found to be predictive of daily functioning $(23,53,66,101,102)$.

\section{Conclusion}

Cochlear implantation allows for access to spoken language and sound for those individuals with hearing loss of a severity that precludes effective amplification with hearing aids. Results from our 12 year experience with CI in older adults $\geq 60$ years demonstrate that cochlear implantation in adults consistently resulted in improved speech understanding scores. Our findings suggest that older adults who are younger at implantation and with higher preoperative speech scores may derive the greatest benefit from cochlear implantation. The expansion of current Medicare policy to allow for cochlear implantation at pre-operative speech score between 40-60\% should be considered to allow for cochlear implantation in older adults at younger ages and at higher preoperative speech scores. Future research into $\mathrm{CI}$ in older adults should expand beyond simple speech outcomes to take into 
account the broad cognitive, social, and physical functioning outcomes that are likely detrimentally impacted by hearing loss and may be mitigated by cochlear implantation.

\section{Acknowledgments}

Sources of support: K23DC011279 (F. R. L. ), R01DC004797 (J. K. N)

\section{Abbreviations}

$\begin{array}{ll}\text { ARHL } & \text { age-related hearing loss } \\ \text { BLSA } & \text { Baltimore Longitudinal Study of Aging } \\ \text { CI } & \text { cochlear implantation } \\ \text { CMS } & \text { Center for Medicare Services } \\ \text { dB } & \text { Decibel } \\ \text { GWAS } & \text { genome wide association studies } \\ \text { NHANES } & \text { National Health and Nutrition Examination Survey } \\ \text { PTA } & \text { pure tone average }\end{array}$

\section{References}

1. Agrawal Y, Platz EA, Niparko JK. Prevalence of hearing loss and differences by demographic characteristics among US adults: data from the National Health and Nutrition Examination Survey, 1999-2004. Arch Intern Med. 2008; 168:1522-1530. [PubMed: 18663164]

2. Appollonio I, Carabellese C, Frattola L, Trabucchi M. Effects of sensory aids on the quality of life and mortality of elderly people: a multivariate analysis. Age Ageing. 1996; 25:89-96. [PubMed: 8670534]

3. Ates NA, Unal M, Tamer L, Derici E, Karakas S, Ercan B, Pata YS, Akbas Y, Vayisoglu Y, Camdeviren H. Glutathione S-transferase gene polymorphisms in presbycusis. Otol Neurotol. 2005; 26:392-397. [PubMed: 15891640]

4. Barnes DE, Cauley JA, Lui LY, Fink HA, McCulloch C, Stone KL, Yaffe K. Women who maintain optimal cognitive function into old age. J Am Geriatr Soc. 2007; 55:259-264. [PubMed: 17302664]

5. Barnes LL, Mendes de Leon CF, Wilson RS, Bienias JL, Evans DA. Social resources and cognitive decline in a population of older African Americans and whites. Neurology. 2004; 63:2322-2326. [PubMed: 15623694]

6. Barnett S, Franks P. Deafness and mortality: analyses of linked data from the National Health Interview Survey and National Death Index. Public Health Rep. 1999; 114:330-6. [PubMed: 10501133]

7. Barrenas ML, Axelsson A. The development of melanin in the stria vascularis of the gerbil. Acta Otolaryngol. 1992; 112:50-58. [PubMed: 1575037]

8. Bartels S, Ito S, Trune DR, Nuttall AL. Noise-induced hearing loss: the effect of melanin in the stria vascularis. Hear Res. 2001; 154:116-123. [PubMed: 11423222]

9. Bassuk SS, Glass TA, Berkman LF. Social disengagement and incident cognitive decline in community-dwelling elderly persons. Ann Intern Med. 1999; 131:165-173. [PubMed: 10428732]

10. Beland F, Zunzunegui MV, Alvarado B, Otero A, Del Ser T. Trajectories of cognitive decline and social relations. J Gerontol B Psychol Sci Soc Sci. 2005; 60:320-330.

11. Berkman LF, Glass T, Brissette I, Seeman TE. From social integration to health: Durkheim in the new millennium. Soc Sci Med. 2000; 51:843-857. [PubMed: 10972429]

12. Bess FH, Lichtenstein MJ, Logan SA, Burger MC, Nelson E. Hearing impairment as a determinant of function in the elderly. J Am Geriatr Soc. 1989; 37:123-8. [PubMed: 2910970] 
13. Bickel H, Cooper B. Incidence and relative risk of dementia in an urban elderly population: findings of a prospective field study. Psychol Med. 1994; 24:179-192. [PubMed: 8208883]

14. Boyle PA, Wilson RS, Schneider JA, Bienias JL, Bennett DA. Processing resources reduce the effect of Alzheimer pathology on other cognitive systems. Neurology. 2008; 70:1534-1542. [PubMed: 18354077]

15. Brant LJ, Fozard JL. Age changes in pure-tone hearing thresholds in a longitudinal study of normal human aging. J Acoust Soc Am. 1990; 88:813-820. [PubMed: 2212307]

16. Brant LJ, Gordon-Salant S, Pearson JD, Klein LL, Morrell CH, Metter EJ, Fozard JL. Risk factors related to age-associated hearing loss in the speech frequencies. J Am Acad Audiol. 1996; 7:152160. [PubMed: 8780987]

17. Brink P, Stones M. Examination of the relationship among hearing impairment, linguistic communication, mood, and social engagement of residents in complex continuing-care facilities. Gerontologist. 2007; 47:633-641. [PubMed: 17989405]

18. Broadhead WE, Kaplan BH, James SA, Wagner EH, Schoenbach VJ, Grimson R, Heyden S, Tibblin G, Gehlbach SH. The epidemiologic evidence for a relationship between social support and health. Am J Epidemiol. 1983; 117:521-37. [PubMed: 6342368]

19. Cabeza R, Nyberg L. Imaging cognition II: An empirical review of 275 PET and fMRI studies. J Cogn Neurosci. 2000; 12:1-47. [PubMed: 10769304]

20. Cacciatore F, Napoli C, Abete P, Marciano E, Triassi M, Rengo F. Quality of life determinants and hearing function in an elderly population: Osservatorio Geriatrico Campano Study Group. Gerontology. 1999; 45:323-328. [PubMed: 10559650]

21. Cacioppo JT, Hawkley LC. Perceived social isolation and cognition. Trends Cogn Sci. 2009; 13:447-454. [PubMed: 19726219]

22. Carabellese C, Appollonio I, Rozzini R, Bianchetti A, Frisoni GB, Frattola L, Trabucchi M. Sensory impairment and quality of life in a community elderly population. J Am Geriatr Soc. 1993; 41:401-407. [PubMed: 8463527]

23. Carlson MC, Fried LP, Xue QL, Bandeen-Roche K, Zeger SL, Brandt J. Association between executive attention and physical functional performance in community-dwelling older women. $\mathrm{J}$ Gerontol B Psychol Sci Soc Sci. 1999; 54:S262-S270. [PubMed: 10542828]

24. Carlson ML, Breen JT, Gifford RH, Driscoll CL, Neff BA, Beatty CW, Peterson AM, Olund AP. Cochlear implantation in the octogenarian and nonagenarian. Otol Neurotol. 31:1343-9. [PubMed: 20729782]

25. Cervera TC, Soler MJ, Dasi C, Ruiz JC. Speech recognition and working memory capacity in young-elderly listeners: effects of hearing sensitivity. Can J Exp Psychol. 2009; 63:216-226. [PubMed: 19739905]

26. Chan V, Tong M, Yue V, Wong T, Leung E, Yuen K, van Hasselt A. Performance of older adult cochlear implant users in Hong Kong. Ear Hear. 2007; 28:52S-55S. [PubMed: 17496647]

27. Chia EM, Wang JJ, Rochtchina E, Cumming RR, Newall P, Mitchell P. Hearing impairment and health-related quality of life: the Blue Mountains Hearing Study. Ear Hear. 2007; 28:187-195. [PubMed: 17496670]

28. Christensen K, Frederiksen H, Hoffman HJ. Genetic and environmental influences on self-reported reduced hearing in the old and oldest old. J Am Geriatr Soc. 2001; 49:1512-1517. [PubMed: 11890591]

29. Cole SW, Hawkley LC, Arevalo JM, Cacioppo JT. Transcript origin analysis identifies antigenpresenting cells as primary targets of socially regulated gene expression in leukocytes. Proc Natl Acad Sci U S A. 108:3080-5. [PubMed: 21300872]

30. Cole SW, Hawkley LC, Arevalo JM, Sung CY, Rose RM, Cacioppo JT. Social regulation of gene expression in human leukocytes. Genome Biol. 2007; 8:R189. [PubMed: 17854483]

31. Coley N, Andrieu S, Gardette V, Gillette-Guyonnet S, Sanz C, Vellas B, Grand A. Dementia prevention: methodological explanations for inconsistent results. Epidemiol Rev. 2008; 30:35-66. [PubMed: 18779228]

32. Cooper JC Jr . Health and Nutrition Examination Survey of 1971-75: Part I. Ear and race effects in hearing. J Am Acad Audiol. 1994; 5:30-36. [PubMed: 8155892] 
33. Cruickshanks KJ, Klein R, Klein BE, Wiley TL, Nondahl DM, Tweed TS. Cigarette smoking and hearing loss: the epidemiology of hearing loss study. JAMA. 1998; 279:1715-1719. [PubMed: 9624024]

34. Cruickshanks KJ, Tweed TS, Wiley TL, Klein BE, Klein R, Chappell R, Nondahl DM, Dalton DS. The 5-year incidence and progression of hearing loss: the epidemiology of hearing loss study. Arch Otolaryngol Head Neck Surg. 2003; 129:1041-1046. [PubMed: 14568784]

35. Cruickshanks KJ, Wiley TL, Tweed TS, Klein BE, Klein R, Mares-Perlman JA, Nondahl DM. Prevalence of hearing loss in older adults in Beaver Dam, Wisconsin. The Epidemiology of Hearing Loss Study. Am J Epidemiol. 1998; 148:879-886. [PubMed: 9801018]

36. Dalton DS, Cruickshanks KJ, Klein BE, Klein R, Wiley TL, Nondahl DM. The impact of hearing loss on quality of life in older adults. Gerontologist. 2003; 43:661-668. [PubMed: 14570962]

37. Dalton DS, Cruickshanks KJ, Klein R, Klein BE, Wiley TL. Association of NIDDM and hearing loss. Diabetes Care. 1998; 21:1540-1544. [PubMed: 9727906]

38. Dror AA, Avraham KB. Hearing loss: mechanisms revealed by genetics and cell biology. Annu Rev Genet. 2009; 43:411-437. [PubMed: 19694516]

39. Dubno JR, Dirks DD, Morgan DE. Effects of age and mild hearing loss on speech recognition in noise. J Acoust Soc Am. 1984; 76:87-96. [PubMed: 6747116]

40. Durkheim, E. Suicide. New York: Free Press; 1897. p. 1951

41. Francis HW, Chee N, Yeagle J, Cheng A, Niparko JK. Impact of cochlear implants on the functional health status of older adults. Laryngoscope. 2002; 112:1482-1488. [PubMed: 12172266]

42. Fratiglioni L, Wang HX, Ericsson K, Maytan M, Winblad B. Influence of social network on occurrence of dementia: a community-based longitudinal study. Lancet. 2000; 355:1315-1319. [PubMed: 10776744]

43. Freedman VA, Berkman LF, Rapp SR, Ostfeld AM. Family networks: predictors of nursing home entry. Am J Public Health. 1994; 84:843-845. [PubMed: 8179059]

44. Friedland DR, Venick HS, Niparko JK. Choice of ear for cochlear implantation: the effect of history and residual hearing on predicted postoperative performance. Otol Neurotol. 2003; 24:582-9. [PubMed: 12851549]

45. Gates GA, Cobb JL, D'Agostino RB, Wolf PA. The relation of hearing in the elderly to the presence of cardiovascular disease and cardiovascular risk factors. Arch Otolaryngol Head Neck Surg. 1993; 119:156-161. [PubMed: 8427676]

46. Gates GA, Cooper JC Jr, Kannel WB, Miller NJ. Hearing in the elderly: the Framingham cohort, 1983-1985. Part I. Basic audiometric test results. Ear Hear. 1990; 11:247-256. [PubMed: 2210098]

47. Gates GA, Couropmitree NN, Myers RH. Genetic associations in age-related hearing thresholds. Arch Otolaryngol Head Neck Surg. 1999; 125:654-659. [PubMed: 10367922]

48. Gifford RH, Shallop JK, Peterson AM. Speech recognition materials and ceiling effects: considerations for cochlear implant programs. Audiol Neurootol. 2008; 13:193-205. [PubMed: 18212519]

49. Glass TA, De Leon CF, Bassuk SS, Berkman LF. Social engagement and depressive symptoms in late life: longitudinal findings. J Aging Health. 2006; 18:604-628. [PubMed: 16835392]

50. Gopinath B, Rochtchina E, Wang JJ, Schneider J, Leeder SR, Mitchell P. Prevalence of age-related hearing loss in older adults: Blue Mountains Study. Arch Intern Med. 2009; 169:415-416. [PubMed: 19237727]

51. Gordon-Salant S. Hearing loss and aging: new research findings and clinical implications. J Rehabil Res Dev. 2005; 42:9-24. [PubMed: 16470462]

52. Gordon MS, Daneman M, Schneider BA. Comprehension of speeded discourse by younger and older listeners. Exp Aging Res. 2009; 35:277-296. [PubMed: 19449242]

53. Grigsby J, Kaye K, Baxter J, Shetterly SM, Hamman RF. Executive cognitive abilities and functional status among community-dwelling older persons in the San Luis Valley Health and Aging Study. J Am Geriatr Soc. 1998; 46:590-596. [PubMed: 9588372]

54. Halling DC, Humes LE. Factors affecting the recognition of reverberant speech by elderly listeners. J Speech Lang Hear Res. 2000; 43:414-431. [PubMed: 10757693] 
55. Heinrich A, Schneider BA, Craik FI. Investigating the influence of continuous babble on auditory short-term memory performance. Q J Exp Psychol (Colchester ). 2008; 61:735-751.

56. Helmer C, Damon D, Letenneur L, Fabrigoule C, Barberger-Gateau P, Lafont S, Fuhrer R, Antonucci T, Commenges D, Orgogozo JM, Dartigues JF. Marital status and risk of Alzheimer's disease: a French population-based cohort study. Neurology. 1999; 53:1953-1958. [PubMed: 10599764]

57. Helzner EP, Cauley JA, Pratt SR, Wisniewski SR, Zmuda JM, Talbott EO, de RN, Harris TB, Rubin SM, Simonsick EM, Tylavsky FA, Newman AB. Race and sex differences in age-related hearing loss: the Health, Aging and Body Composition Study. J Am Geriatr Soc. 2005; 53:21192127. [PubMed: 16398896]

58. Herbst KG, Humphrey C. Hearing impairment and mental state in the elderly living at home. $\mathrm{Br}$ Med J. 1980; 281:903-905. [PubMed: 7427503]

59. Holtzman RE, Rebok GW, Saczynski JS, Kouzis AC, Wilcox DK, Eaton WW. Social network characteristics and cognition in middle-aged and older adults. J Gerontol B Psychol Sci Soc Sci. 2004; 59:278-284.

60. House JS, Landis KR, Umberson D. Social relationships and health. Science. 1988; 241:540-545. [PubMed: 3399889]

61. Humes LE, Watson BU, Christensen LA, Cokely CG, Halling DC, Lee L. Factors associated with individual differences in clinical measures of speech recognition among the elderly. J Speech Hear Res. 1994; 37:465-474. [PubMed: 8028328]

62. Huyghe JR, Van LL, Hendrickx JJ, Fransen E, Demeester K, Topsakal V, Kunst S, Manninen M, Jensen M, Bonaconsa A, Mazzoli M, Baur M, Hannula S, Maki-Torkko E, Espeso A, Van EE, Flaquer A, Becker C, Stephens D, Sorri M, Orzan E, Bille M, Parving A, Pyykko I, Cremers CW, Kremer H, Van de Heyning PH, Wienker TF, Nurnberg P, Pfister M, Van CG. Genome-wide SNP-based linkage scan identifies a locus on 8q24 for an age-related hearing impairment trait. Am J Hum Genet. 2008; 83:401-407. [PubMed: 18760390]

63. Ishii EK, Talbott EO. Race/ethnicity differences in the prevalence of noise-induced hearing loss in a group of metal fabricating workers. J Occup Environ Med. 1998; 40:661-666. [PubMed: 9729747]

64. Ives DG, Bonino P, Traven ND, Kuller LH. Characteristics and comorbidities of rural older adults with hearing impairment. J Am Geriatr Soc. 1995; 43:803-806. [PubMed: 7602037]

65. Jerger J, Jerger S, Pepe P, Miller R. Race difference in susceptibility to noise-induced hearing loss. Am J Otol. 1986; 7:425-429. [PubMed: 3812644]

66. Johnson JK, Lui LY, Yaffe K. Executive function, more than global cognition, predicts functional decline and mortality in elderly women. J Gerontol A Biol Sci Med Sci. 2007; 62:1134-1141. [PubMed: 17921427]

67. Jones DA, Victor CR, Vetter NJ. Hearing difficulty and its psychological implications for the elderly. J Epidemiol Community Health. 1984; 38:75-78. [PubMed: 6231351]

68. Kahneman, D. Attention and effort. Englewood Cliffs, NJ: Prentice-Hall; 1973.

69. Kalayam B, Meyers BS, Kakuma T, Alexopoulos GS, Young RC, Solomon S, Shotland R, Nambudiri D, Goldsmith D. Age at onset of geriatric depression and sensorineural hearing deficits. Biol Psychiatry. 1995; 38:649-658. [PubMed: 8555376]

70. Karlsson KK, Harris JR, Svartengren M. Description and primary results from an audiometric study of male twins. Ear Hear. 1997; 18:114-120. [PubMed: 9099560]

71. Karp A, Paillard-Borg S, Wang HX, Silverstein M, Winblad B, Fratiglioni L. Mental, physical and social components in leisure activities equally contribute to decrease dementia risk. Dement Geriatr Cogn Disord. 2006; 21:65-73. [PubMed: 16319455]

72. Kawachi I, Berkman LF. Social ties and mental health. J Urban Health. 2001; 78:458-467. [PubMed: 11564849]

73. Konings A, Van LL, Van CG. Genetic studies on noise-induced hearing loss: a review. Ear Hear. 2009; 30:151-159. [PubMed: 19194285]

74. Kramer SE, Kapteyn TS, Kuik DJ, Deeg DJ. The association of hearing impairment and chronic diseases with psychosocial health status in older age. J Aging Health. 2002; 14:122-137.

[PubMed: 11892756] 
75. Leung J, Wang NY, Yeagle JD, Chinnici J, Bowditch S, Francis HW, Niparko JK. Predictive models for cochlear implantation in elderly candidates. Arch Otolaryngol Head Neck Surg. 2005; 131:1049-54. [PubMed: 16365217]

76. Lin FR. Hearing loss and cognition among older adults in the United States. J Gerontol A Biol Sci Med Sci. 2011; 66:1131-6. [PubMed: 21768501]

77. Lin FR, Ferrucci L, Metter EJ, An Y, Zonderman AB, Resnick SM. Hearing loss and cognition in the Baltimore longitudinal study of aging. Neuropsychology. 2011

78. Lin FR, Metter EJ, O'Brien RJ, Resnick SM, Zonderman AB, Ferrucci L. Hearing loss and incident dementia. Arch Neurol. 2011; 68:214-20. [PubMed: 21320988]

79. Lin FR, Niparko JK, Ferrucci L. Hearing loss prevalence in the United States. Arch Intern Med. 2011 In press.

80. Lin FR, Thorpe R, Gordon-Salant S, Ferrucci L. Hearing loss prevalence and risk factors among older adults in the United States. J Gerontol A Biol Sci Med Sci. 2011; 66:582-90. [PubMed: 21357188]

81. Liu XZ, Yan D. Ageing and hearing loss. J Pathol. 2007; 211:188-197. [PubMed: 17200945]

82. Luce PA, Feustel TC, Pisoni DB. Capacity demands in short-term memory for synthetic and natural speech. Hum Factors. 1983; 25:17-32. [PubMed: 6840769]

83. McCoy SL, Tun PA, Cox LC, Colangelo M, Stewart RA, Wingfield A. Hearing loss and perceptual effort: downstream effects on older adults' memory for speech. Q J Exp Psychol A. 2005; 58:22-33. [PubMed: 15881289]

84. Migirov L, Taitelbaum-Swead R, Drendel M, Hildesheimer M, Kronenberg J. Cochlear implantation in elderly patients: surgical and audiological outcome. Gerontology. 2010; 56:123-8. [PubMed: 19713692]

85. Mor V, Murphy J, Masterson-Allen S, Willey C, Razmpour A, Jackson ME, Greer D, Katz S. Risk of functional decline among well elders. J Clin Epidemiol. 1989; 42:895-904. [PubMed: 2778468]

86. Mulrow CD, Aguilar C, Endicott JE, Tuley MR, Velez R, Charlip WS, Rhodes MC, Hill JA, DeNino LA. Quality-of-life changes and hearing impairment. A randomized trial. Ann Intern Med. 1990; 113:188-194. [PubMed: 2197909]

87. Murphy DR, Craik FI, Li KZ, Schneider BA. Comparing the effects of aging and background noise on short-term memory performance. Psychol Aging. 2000; 15:323-334. [PubMed: 10879586]

88. Murphy DR, Daneman M, Schneider BA. Why do older adults have difficulty following conversations? Psychol. Aging. 2006; 21:49-61.

89. NeuropathologyGroup . Pathological correlates of late-onset dementia in a multicentre, community-based population in England and Wales. Neuropathology Group of the Medical Research Council Cognitive Function and Ageing Study (MRC CFAS). Lancet. 2001; 357:16975. [PubMed: 11213093]

90. Ohlemiller KK. Age-related hearing loss: the status of Schuknecht's typology. Curr Opin Otolaryngol Head Neck Surg. 2004; 12:439-443. [PubMed: 15377958]

91. Ohlemiller KK. Mechanisms and genes in human strial presbycusis from animal models. Brain Res. 2009; 1277:70-83. [PubMed: 19285967]

92. Oxman TE, Berkman LF, Kasl S, Freeman DH Jr, Barrett J. Social support and depressive symptoms in the elderly. Am J Epidemiol. 1992; 135:356-368. [PubMed: 1550090]

93. Palmore EB, Nowlin JB, Wang HS. Predictors of function among the old-old: a 10-year follow-up. J Gerontol. 1985; 40:244-250. [PubMed: 3973367]

94. Pichora-Fuller MK, Schneider BA, Daneman M. How young and old adults listen to and remember speech in noise. J Acoust Soc Am. 1995; 97:593-608. [PubMed: 7860836]

95. Pickles, JO. An introduction to the physiology of hearing. Bingley, UK: Emerald Group Publishing; 2008.

96. Rabbitt P. Mild hearing loss can cause apparent memory failures which increase with age and reduce with IQ. Acta Otolaryngol Suppl. 1990; 476:167-75. discussion 176. 167-175. [PubMed: 2087959]

97. Rabbitt PM. Channel-capacity, intelligibility and immediate memory. Q J Exp Psychol. 1968; 20:241-248. [PubMed: 5683763] 
98. Reed D, McGee D, Yano K, Feinleib M. Social networks and coronary heart disease among Japanese men in Hawaii. Am J Epidemiol. 1983; 117:384-396. [PubMed: 6837553]

99. Resnick HE, Fries BE, Verbrugge LM. Windows to their world: the effect of sensory impairments on social engagement and activity time in nursing home residents. J Gerontol B Psychol Sci Soc Sci. 1997; 52:S135-S144. [PubMed: 9158570]

100. Roos NP, Havens B. Predictors of successful aging: a twelve-year study of Manitoba elderly. Am J Public Health. 1991; 81:63-68. [PubMed: 1898500]

101. Royall DR, Palmer R, Chiodo LK, Polk MJ. Declining executive control in normal aging predicts change in functional status: the Freedom House Study. J Am Geriatr Soc. 2004; 52:346-352. [PubMed: 14962147]

102. Royall DR, Palmer R, Chiodo LK, Polk MJ. Executive control mediates memory's association with change in instrumental activities of daily living: the Freedom House Study. J Am Geriatr Soc. 2005; 53:11-17. [PubMed: 15667370]

103. Ruberman W, Weinblatt E, Goldberg JD, Chaudhary BS. Psychosocial influences on mortality after myocardial infarction. N Engl J Med. 1984; 311:552-559. [PubMed: 6749228]

104. Rubinstein JT, Parkinson WS, Tyler RS, Gantz BJ. Residual speech recognition and cochlear implant performance: effects of implantation criteria. Am J Otol. 1999; 20:445-52. [PubMed: 10431885]

105. Saczynski JS, Pfeifer LA, Masaki K, Korf ES, Laurin D, White L, Launer LJ. The effect of social engagement on incident dementia: the Honolulu-Asia Aging Study. Am J Epidemiol. 2006; 163:433-440. [PubMed: 16410348]

106. Salthouse TA. Aging and measures of processing speed. Biol Psychol. 2000; 54:35-54. [PubMed: 11035219]

107. Salthouse TA. The processing-speed theory of adult age differences in cognition. Psychol Rev. 1996; 103:403-428. [PubMed: 8759042]

108. Scarmeas N, Levy G, Tang MX, Manly J, Stern Y. Influence of leisure activity on the incidence of Alzheimer's disease. Neurology. 2001; 57:2236-2242. [PubMed: 11756603]

109. Schmiedt RA, Lang H, Okamura HO, Schulte BA. Effects of furosemide applied chronically to the round window: a model of metabolic presbyacusis. J Neurosci. 2002; 22:9643-9650. [PubMed: 12417690]

110. Schneider BA, Daneman M, Murphy DR. Speech comprehension difficulties in older adults: cognitive slowing or age-related changes in hearing? Psychol. Aging. 2005; 20:261-271.

111. Schneider BA, Daneman M, Murphy DR, See SK. Listening to discourse in distracting settings: the effects of aging. Psychol Aging. 2000; 15:110-125. [PubMed: 10755294]

112. Schneider BA, Li L, Daneman M. How competing speech interferes with speech comprehension in everyday listening situations. J Am Acad Audiol. 2007; 18:559-572. [PubMed: 18236644]

113. Schuknecht HF. Presbycusis. Laryngoscope. 1955; 65:402-19. [PubMed: 14392966]

114. Schuknecht HF, Gacek MR. Cochlear pathology in presbycusis. Ann Otol Rhinol Laryngol. 1993; 102:1-16. [PubMed: 8420477]

115. Schuknecht HF, Watanuki K, Takahashi T, Belal AA Jr, Kimura RS, Jones DD, Ota CY. Atrophy of the stria vascularis, a common cause for hearing loss. Laryngoscope. 1974; 84:1777-821. [PubMed: 4138750]

116. Seeman TE. Health promoting effects of friends and family on health outcomes in older adults. Am J Health Promot. 2000; 14:362-370. [PubMed: 11067571]

117. Seeman TE. Social ties and health: the benefits of social integration. Ann Epidemiol. 1996; 6:442-451. [PubMed: 8915476]

118. Seeman TE, McEwen BS. Impact of social environment characteristics on neuroendocrine regulation. Psychosom Med. 1996; 58:459-471. [PubMed: 8902897]

119. Steinbach U. Social networks, institutionalization, and mortality among elderly people in the United States. J Gerontol. 1992; 47:S183-S190. [PubMed: 1624713]

120. Stern Y. What is cognitive reserve? Theory and research application of the reserve concept. J Int Neuropsychol Soc. 2002; 8:448-460. [PubMed: 11939702] 
121. Strawbridge WJ, Camacho TC, Cohen RD, Kaplan GA. Gender differences in factors associated with change in physical functioning in old age: a 6-year longitudinal study. Gerontologist. 1993; 33:603-609. [PubMed: 8225004]

122. Strawbridge WJ, Wallhagen MI, Shema SJ, Kaplan GA. Negative consequences of hearing impairment in old age: a longitudinal analysis. Gerontologist. 2000; 40:320-326. [PubMed: 10853526]

123. Stuss DT. Biological and psychological development of executive functions. Brain Cogn. 1992; 20:8-23. [PubMed: 1389124]

124. Tambs K. Moderate effects of hearing loss on mental health and subjective well-being: results from the Nord-Trondelag Hearing Loss Study. Psychosom Med. 2004; 66:776-782. [PubMed: 15385706]

125. Thomas A, Herbst KG. Social and psychological implications of acquired deafness for adults of employment age. Br J Audiol. 1980; 14:76-85. [PubMed: 7417728]

126. Tsuruoka H, Masuda S, Ukai K, Sakakura Y, Harada T, Majima Y. Hearing impairment and quality of life for the elderly in nursing homes. Auris Nasus Larynx. 2001; 28:45-54. [PubMed: 11137363]

127. Tun PA, McCoy S, Wingfield A. Aging, hearing acuity, and the attentional costs of effortful listening. Psychol Aging. 2009; 24:761-766. [PubMed: 19739934]

128. Uchino BN. Social support and health: a review of physiological processes potentially underlying links to disease outcomes. J Behav Med. 2006; 29:377-387. [PubMed: 16758315]

129. Uhlmann RF, Larson EB, Rees TS, Koepsell TD, Duckert LG. Relationship of hearing impairment to dementia and cognitive dysfunction in older adults. JAMA. 1989; 261:1916-1919. [PubMed: 2926927]

130. Unal M, Tamer L, Dogruer ZN, Yildirim H, Vayisoglu Y, Camdeviren H. N-acetyltransferase 2 gene polymorphism and presbycusis. Laryngoscope. 2005; 115:2238-2241. [PubMed: 16369173]

131. Van EE, Van CG, Van LL. The complexity of age-related hearing impairment: contributing environmental and genetic factors. Audiol Neurootol. 2007; 12:345-358. [PubMed: 17664866]

132. Van LL, DeStefano AL, Myers RH, Flothmann K, Thys S, Fransen E, Gates GA, Van CG, Baldwin CT. Is DFNA5 a susceptibility gene for age-related hearing impairment? Eur. J Hum Genet. 2002; 10:883-886.

133. Van LL, Van EE, Fransen E, Huyghe JR, Topsakal V, Hendrickx JJ, Hannula S, Maki-Torkko E, Jensen M, Demeester K, Baur M, Bonaconsa A, Mazzoli M, Espeso A, Verbruggen K, Huyghe J, Huygen P, Kunst S, Manninen M, Konings A, Diaz-Lacava AN, Steffens M, Wienker TF, Pyykko I, Cremers CW, Kremer H, Dhooge I, Stephens D, Orzan E, Pfister M, Bille M, Parving A, Sorri M, Van de Heyning PH, Van CG. The grainyhead like 2 gene (GRHL2), alias TFCP2L3, is associated with age-related hearing impairment. Hum Mol Genet. 2008; 17:159-169. [PubMed: 17921507]

134. Vermeire K, Brokx JP, Wuyts FL, Cochet E, Hofkens A, Van de Heyning PH. Quality-of-life benefit from cochlear implantation in the elderly. Otol Neurotol. 2005; 26:188-95. [PubMed: 15793403]

135. Vogt TM, Mullooly JP, Ernst D, Pope CR, Hollis JF. Social networks as predictors of ischemic heart disease, cancer, stroke and hypertension: incidence, survival and mortality. J Clin Epidemiol. 1992; 45:659-666. [PubMed: 1607905]

136. Wallhagen MI, Strawbridge WJ, Shema SJ, Kurata J, Kaplan GA. Comparative impact of hearing and vision impairment on subsequent functioning. J Am Geriatr Soc. 2001; 49:1086-92. [PubMed: 11555071]

137. Wang HX, Karp A, Winblad B, Fratiglioni L. Late-life engagement in social and leisure activities is associated with a decreased risk of dementia: a longitudinal study from the Kungsholmen project. Am J Epidemiol. 2002; 155:1081-1087. [PubMed: 12048221]

138. Weinstein BE, Ventry IM. Hearing impairment and social isolation in the elderly. J Speech Hear Res. 1982; 25:593-9. [PubMed: 7162161]

139. Wiley TL, Cruickshanks KJ, Nondahl DM, Tweed TS, Klein R, Klein BE. Aging and word recognition in competing message. J Am Acad Audiol. 1998; 9:191-198. [PubMed: 9644616] 
140. WorldHealthOrganization. World Health Organization Prevention of Blindness and Deafness (PBD) Program. Prevention of Deafness and Hearing Impaired Grades of Hearing Impairment. http://www.who.int/pbd/deafness/hearing_impairment_grades/en/index.html

141. Zunzunegui MV, Alvarado BE, Del Ser T, Otero A. Social networks, social integration, and social engagement determine cognitive decline in community-dwelling Spanish older adults. J Gerontol B Psychol Sci Soc Sci. 2003; 58:S93-S100. [PubMed: 12646598] 


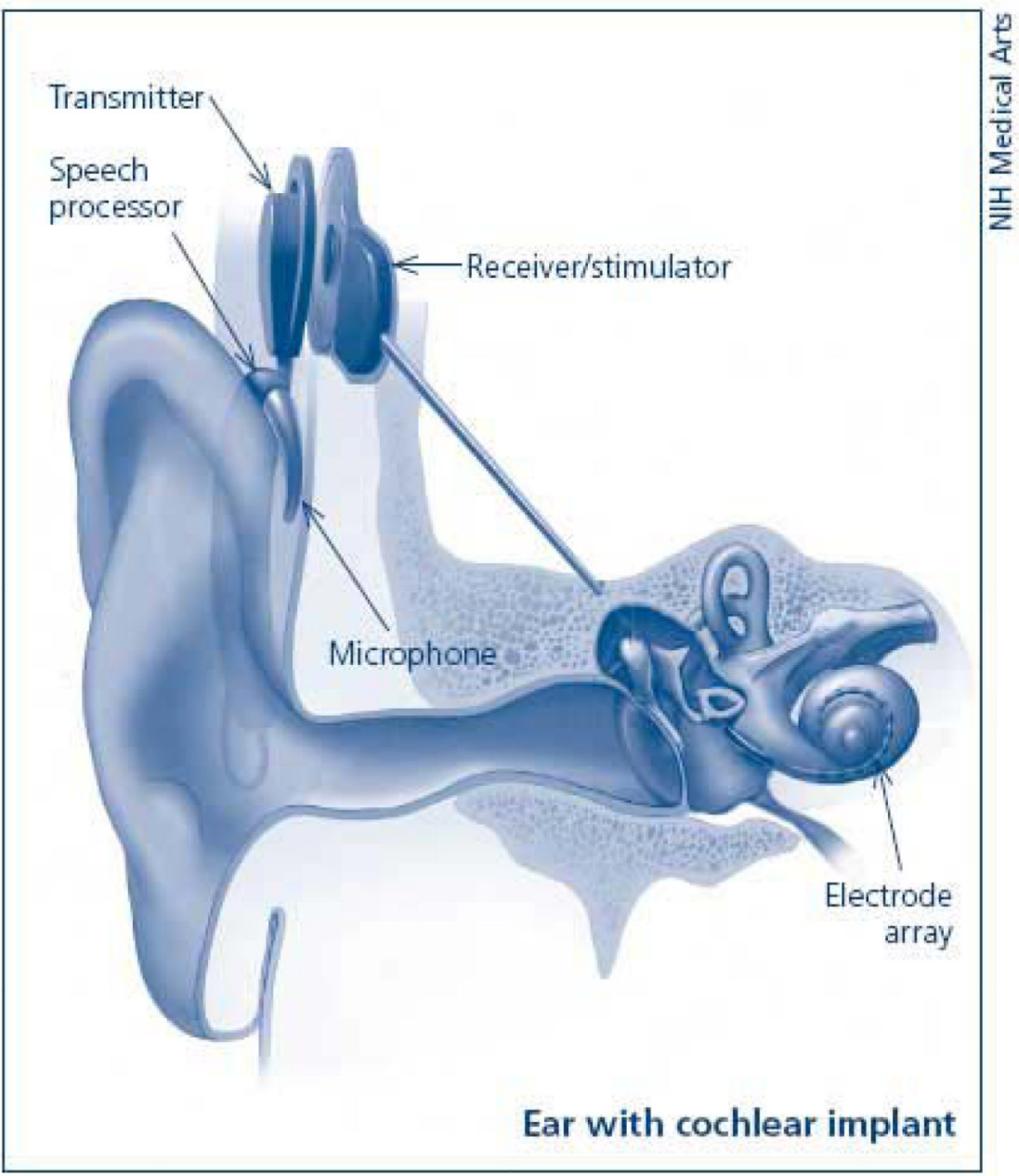

Figure 1.

Schematic illustration of an ear with cochlear implantation. The microphone and the speech processor (external device) receives auditory signals from the external world and transmits the information to the receiver/stimulator (internal device), which is coupled to an electrode array (Illustration created by NIH Medical Arts). 


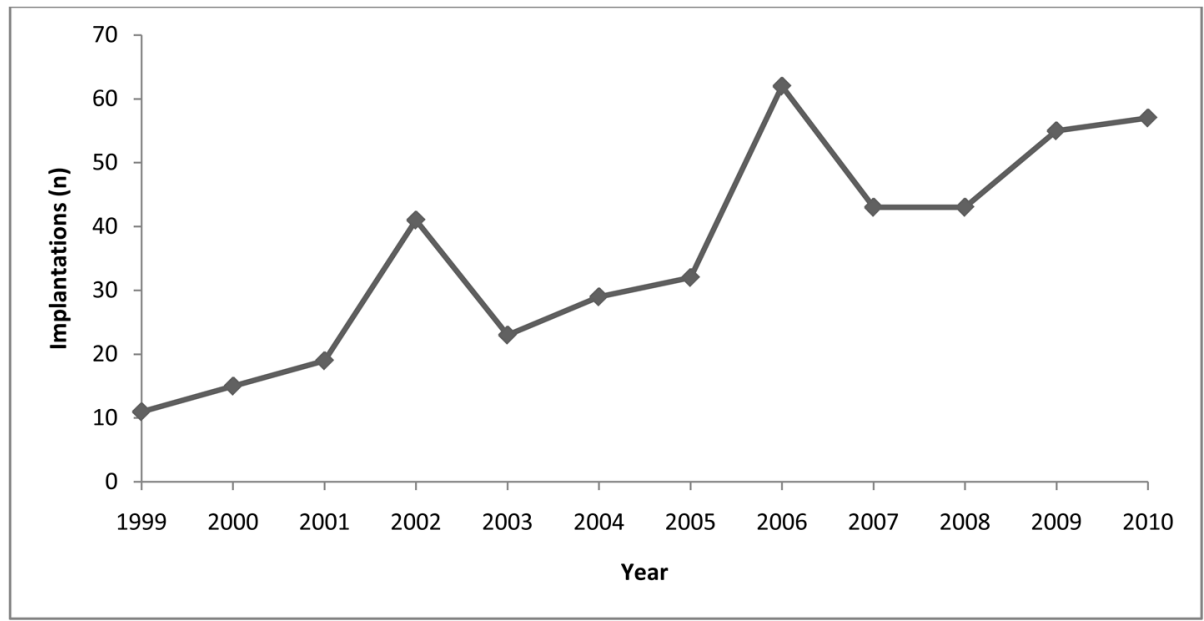

Figure 2.

Number of cochlear implantations performed in adults $\ 60$ years at Johns Hopkins from 1999-2010 


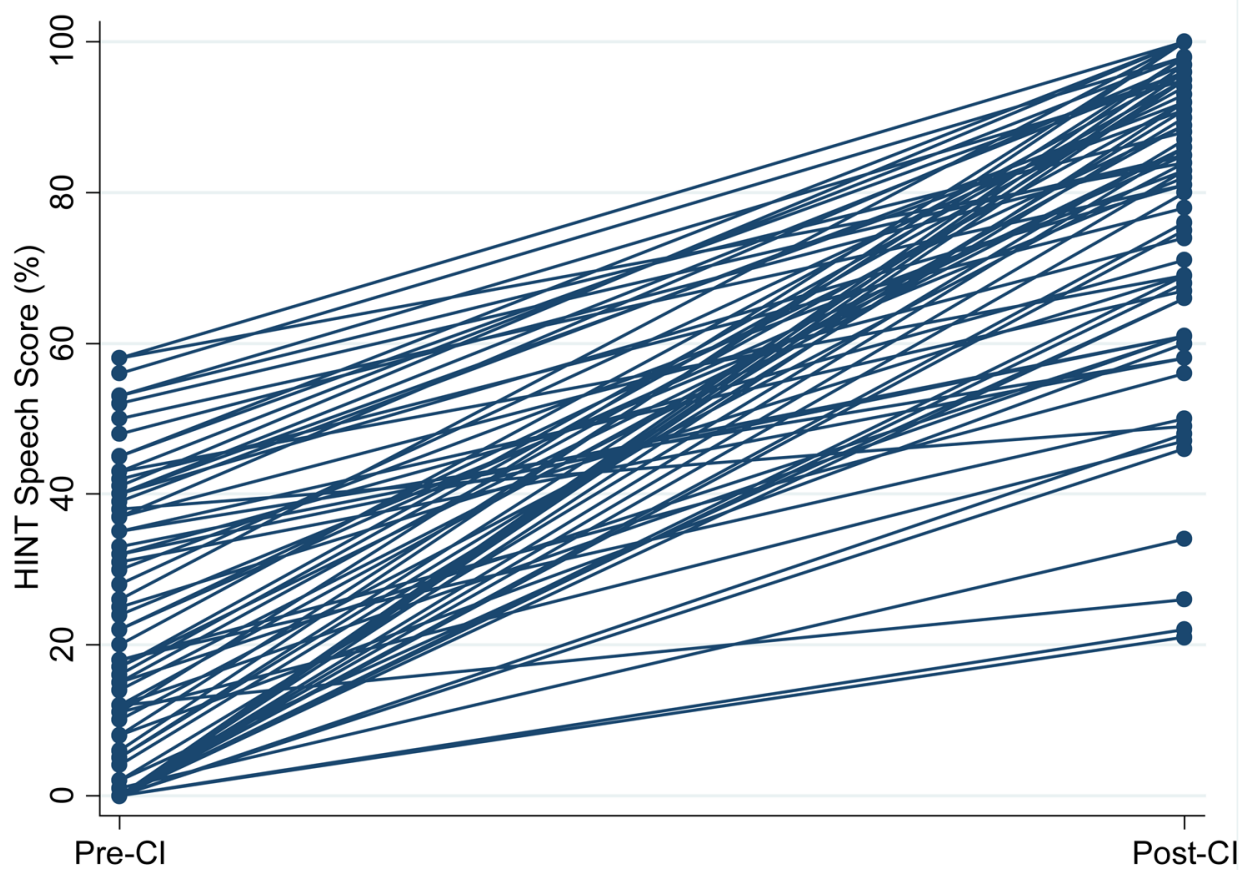

Figure 3.

Pre-CI and 1 year post-CI HINT speech scores in adults $\geq 60$ years, $n=83$ 


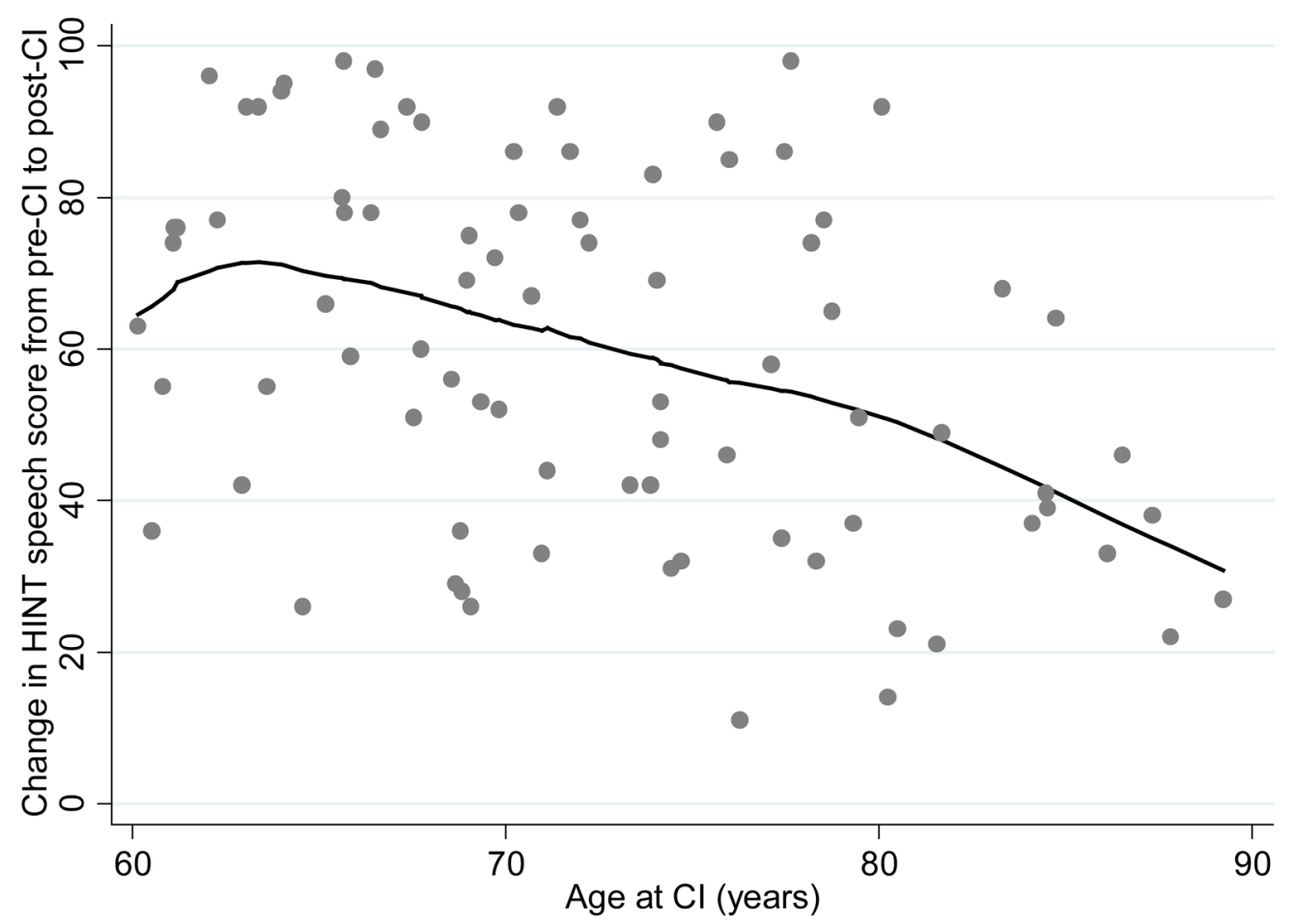

Figure 4.

Change in HINT speech score from pre-CI to 1 year post-CI by age at CI, $n=83$ 

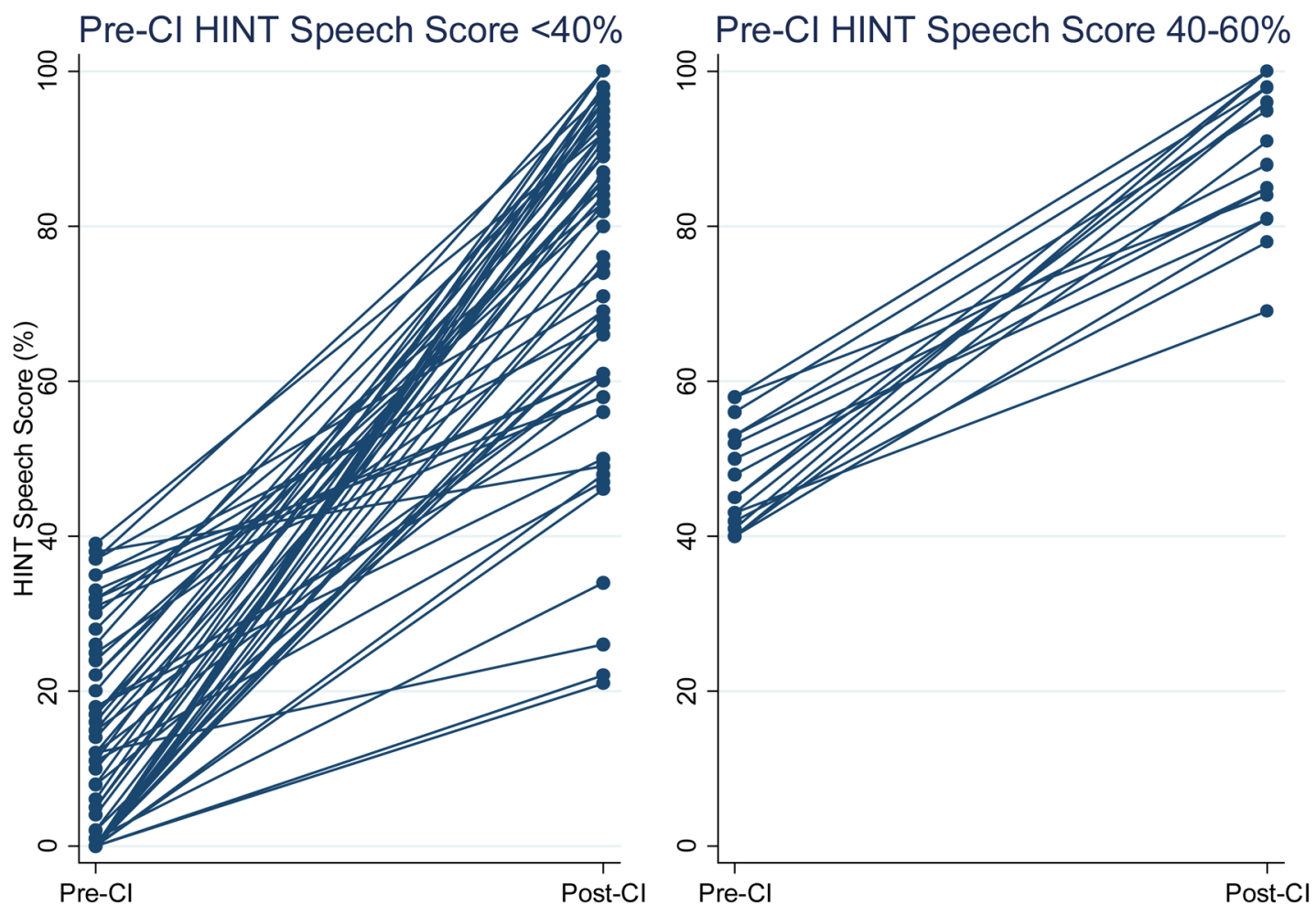

Figure 5.

Pre-CI and 1 year post-CI HINT speech scores by pre-CI speech score, $\mathrm{n}=83$ 


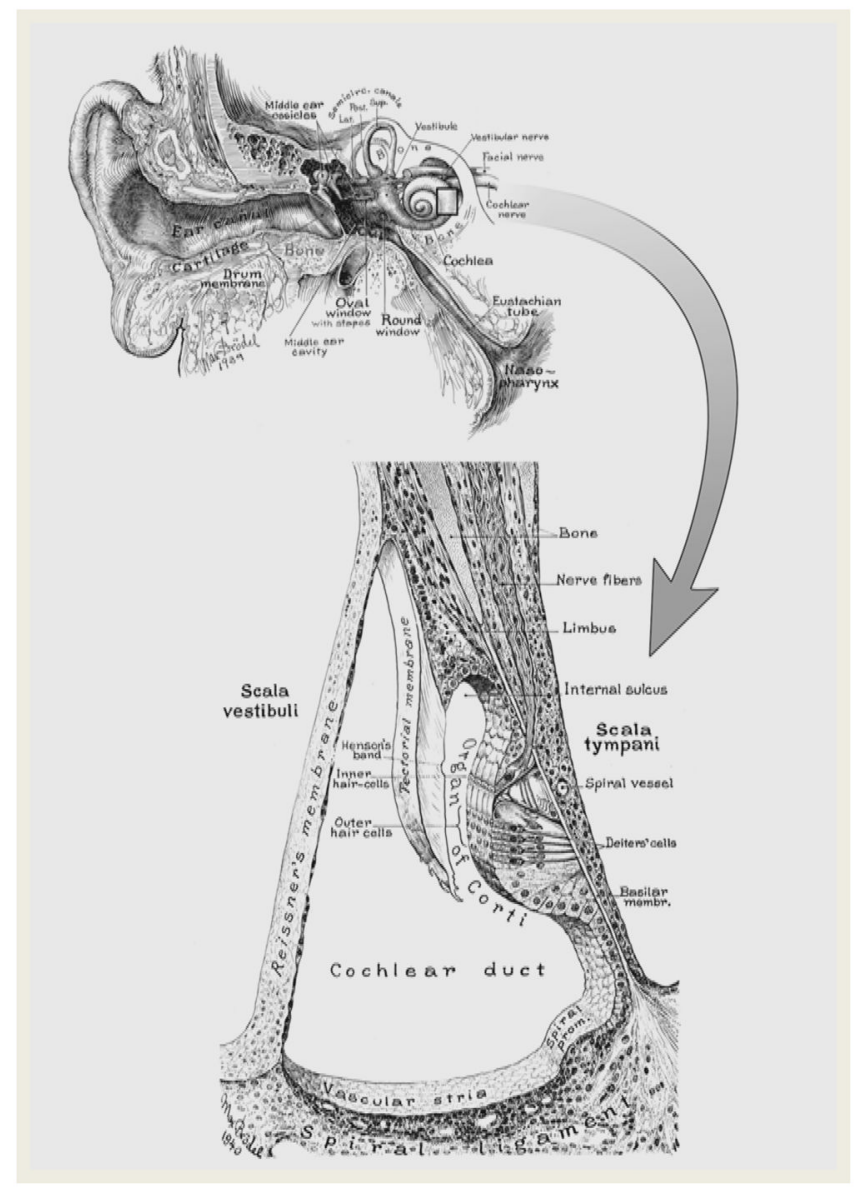

Figure 6.

Schematic representation of cochlear anatomy. The top panel shows a cross section of the human ear, which is divided into 3 parts: external, middle and inner ear. The bottom panel shows the detailed anatomy of the cochlea, in particular the scala media, where the auditory neuroepithelium resides. (Illustration from Johns Hopkins Max Brödel Archives) 


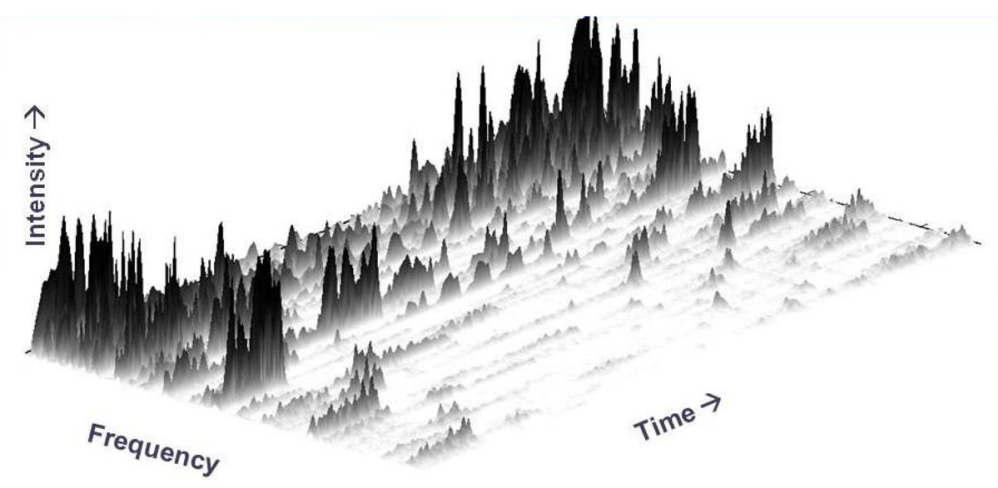

Figure 7.

Three-dimensional spectrogram of a complex sound. Dimensions of a complex sound include frequency, intensity, and time, and all three aspects are encoded through cochlear transduction to afferent neural signals that are transmitted to the brainstem and higher order cortical structures for decoding. 


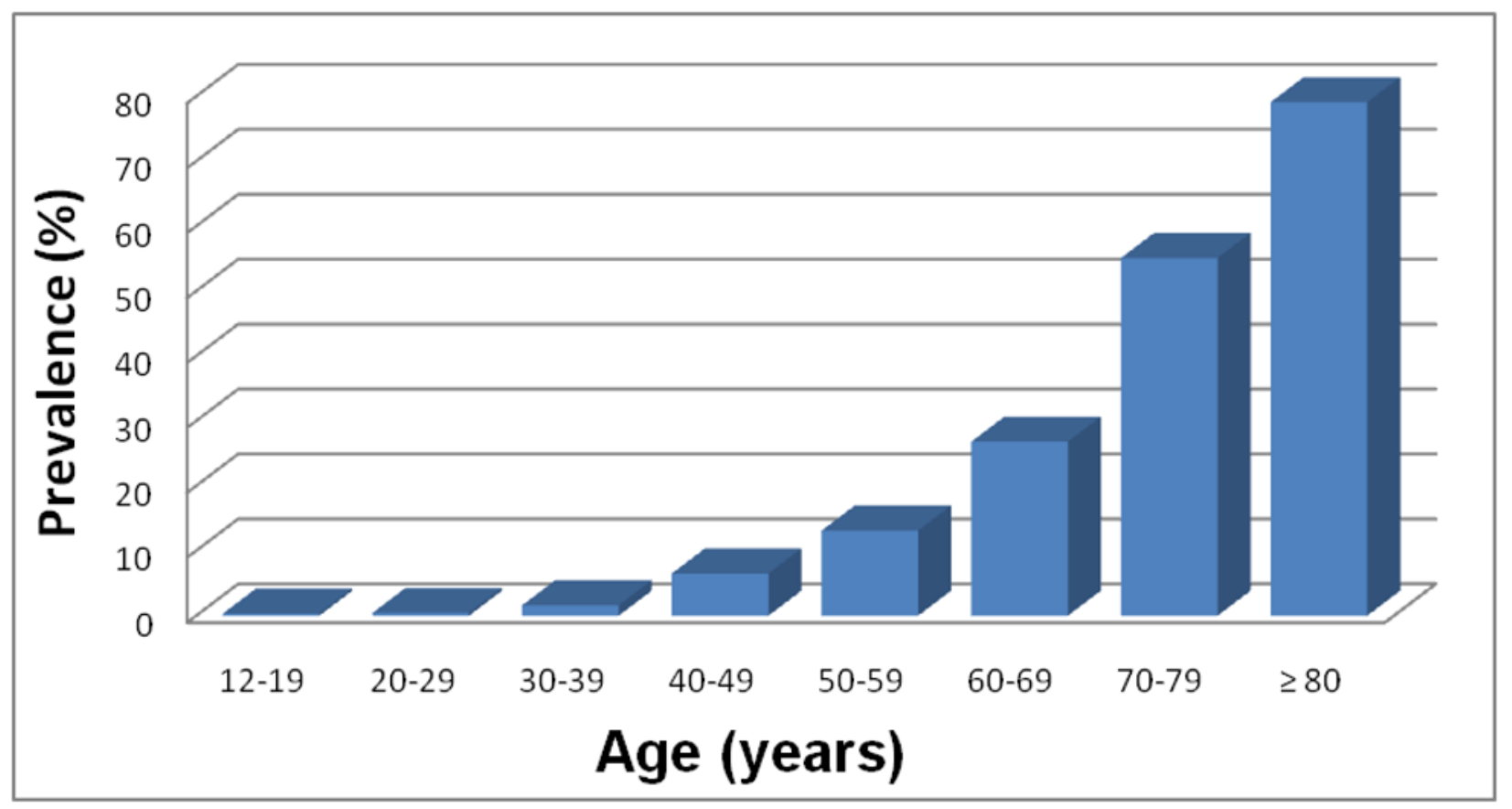

Figure 8.

Prevalence of hearing loss in the United States by age, 2001-2008. 


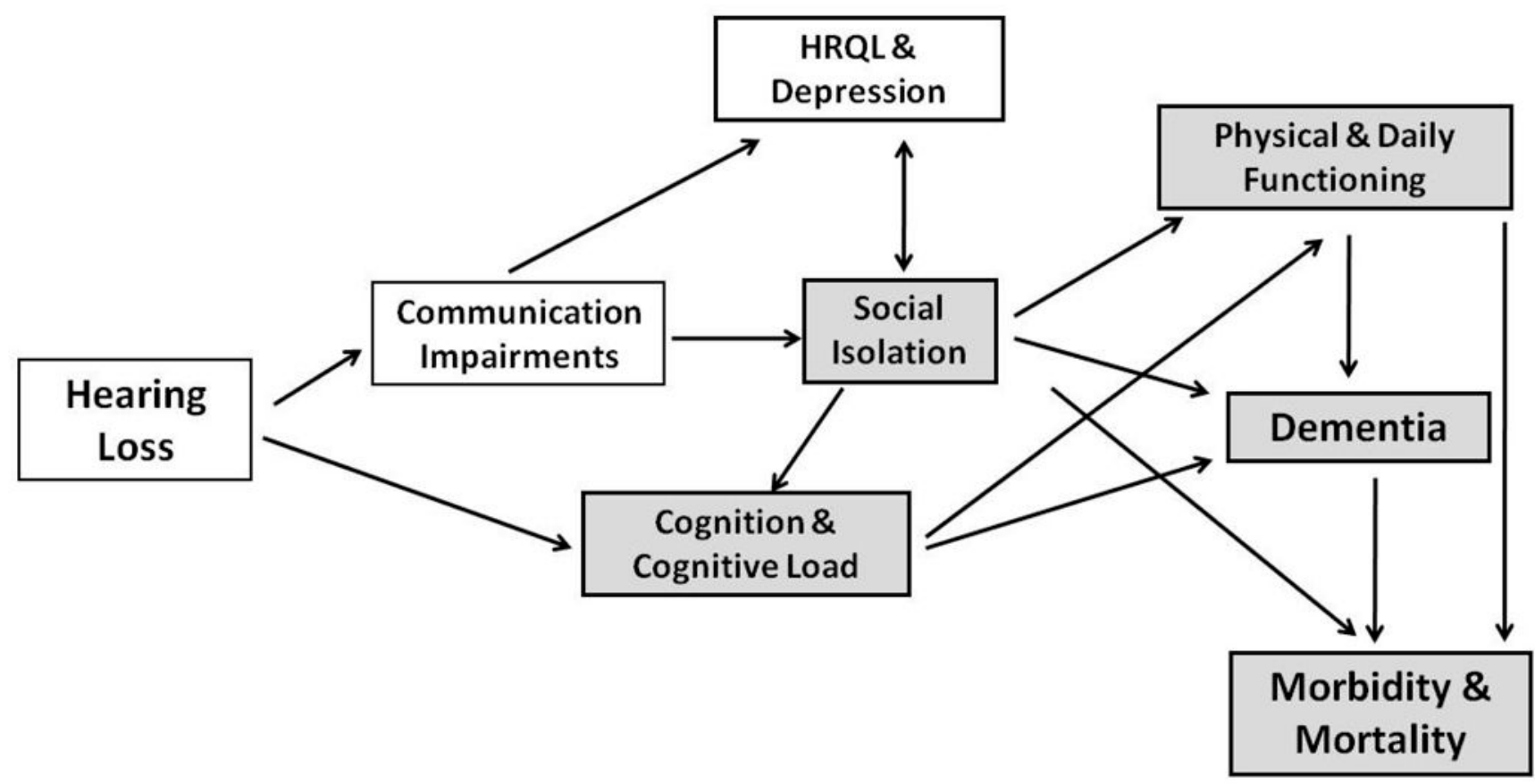

Figure 9.

Conceptual model of how hearing loss affects domains of health and functioning. Unshaded boxes depict domains most commonly studied in hearing research, and shaded boxes correspond to those domains of health and functioning that are central to aging research and public health. 


\section{Cognitive Resource Capacity}

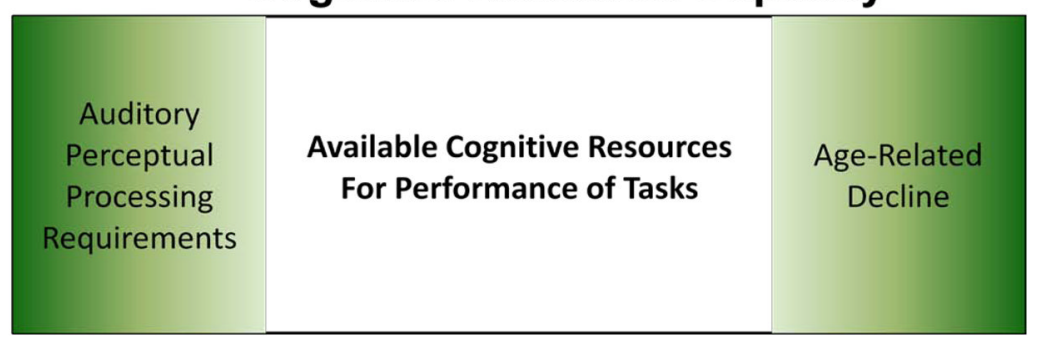

Figure 10.

Cognitive resource capacity is reduced by both auditory perceptual processing requirements and general age-related declines. 


\section{Table 1}

Cohort demographics and cochlear implantation (CI) characteristics of adults $\searrow 60$ years old receiving their first cochlear implant at Johns Hopkins, 1999-2011

\begin{tabular}{|c|c|c|c|c|}
\hline \multirow[b]{2}{*}{ Characteristic } & \multirow[b]{2}{*}{ Full Cohort $N=445$} & \multicolumn{2}{|c|}{$\begin{array}{l}\text { Subcohorts Based on Availability of HINT Speech Data at Baseline \& } \\
\qquad 1 \text { year }\end{array}$} & \multirow[b]{2}{*}{$\mathbf{P}$} \\
\hline & & Incomplete scores $\mathrm{N}=362$ & Complete scores $N=83$ & \\
\hline \multicolumn{5}{|l|}{ Sex } \\
\hline Male & $224(49.7)$ & $190(52.5)$ & $34(41.0)$ & .06 \\
\hline Female & $221(50.3)$ & $172(47.5)$ & $49(59.0)$ & \\
\hline \multicolumn{5}{|l|}{ Age at initial CI, yr } \\
\hline $60-69$ & $184(41.4)$ & $147(40.6)$ & $37(44.6)$ & .89 \\
\hline $70-79$ & $175(39.3)$ & $144(40.0)$ & $31(37.4)$ & \\
\hline $80-89$ & $82(18.4)$ & $67(18.5)$ & $15(18.1)$ & \\
\hline $90-100$ & $4(0.9)$ & $4(1.1)$ & $0(0)$ & \\
\hline Mean age, yr (SD) [Range] & 72.7 (7. 7) [60.0-94.9] & 72.7 (7. 7) [60. $0-94.9]$ & $72.4(7.6)[60.1-89.2]$ & \\
\hline \multicolumn{5}{|l|}{ Onset of Hearing Loss * } \\
\hline$<18 y r s$ & $65(14.6)$ & $55(16.9)$ & $10(12.7)$ & 35 \\
\hline 218 yrs & $339(76.2)$ & $270(83.1)$ & $69(87.3)$ & \\
\hline \multicolumn{5}{|l|}{ Side Implanted } \\
\hline Right ear & $238(53.5)$ & $195(53.9)$ & $43(51.8)$ & .73 \\
\hline Left ear & 207 (46. 5) & $167(46.1)$ & $40(48.2)$ & \\
\hline
\end{tabular}

All values are $\mathrm{n}(\%)$ unless otherwise indicated.

$41(9.2 \%)$ subjects had missing HL age of onset 